Febrinda Setyo Damayanti ${ }^{1}$, Moses Glorino Rumambo Pandin ${ }^{2}$

Airlangga University

J1. Airlangga No. 4-6, Airlangga, Kec. Gubeng, Kota Surabaya, Jawa Timur 60115

febrinda.setyo.damayanti-2020@fib.unair.ac.id; moses.glorino@fib.unair.ac.id

\title{
BOOK REVIEW: \\ Axiology: as the Basis for Developing the Personality of the Indonesian Nation and State \\ (Aksiologi: Sebagai Dasar Pembinaan Kepribadian Bangsa Dan Negara Indonesia)
}

Jirzanah: Yogyakarta; 2020; ISBN 978-602-386-426-3; x + 190 pp.

This book has been written to analyze and explain the morals of the Indonesian nation's actions by Pancasila from an axiological point of view. In addition, it also provides benefits for several other aspects, such as science and philosophy. We can use it as a reference or consideration about science. It can be a reference to the scope of practical and empirical experience. In the sight of philosophy, it can become a reference that philosophy has more functional meaning than as an activity of rational thinking. This book might be a reference for the Indonesian people in facing the flow of globalization and modernization. So that Indonesia can uphold the nation's guidelines, namely Pancasila.

The book describes axiology and its effects on several aspects of science. It shows the attitude of the Indonesian by the nation's guidelines which is known as the axiological point of view of Pancasila. It also explains the ethics and morals that the Indonesian people should uphold in facing current modernization. It is not only suitable for students but also for the younger generation and the general public.

This book presents some new knowledge about axiology and its relationship with ethics, morals based on Pancasila. It also explains how axiology relates to the life of the Indonesian nation and society. It tells that the Morality of Pancasila is a moral value that has rooted in the Indonesian people's personalities. This personality is the characteristic of Indonesia that makes the Indonesian people different from anyone from other countries. Pancasila has a unified unity because each Pancasila principle is related to one another. In addition, Pancasila has a pyramidal structure, where the first precept, namely the One Godhead, is the basis of the other precepts. Pancasila morale is a prime ethical system that forms from the values and morals of the Indonesian nation and society. Then Pancasila is prioritized as an ethical system that is a moral personality of the country. The morality of Pancasila is a reflection of the principle of values. Currently, the Indonesian state is in a period of change towards the modern world and is experiencing various upheavals. To reach modern society and better life, Indonesian people must be strong and keep integrated.

This book has been reviewed because it is attractive and provides a lot of new knowledge for readers. We reviewed it to give an overview of the book. So the reader can understand the book before buying and reading the whole book. In addition, readers can compare the results of this reviewer with what they get after reading it.

This book is very good at explaining axiology and its effects on several aspects of science, as well as showing how the attitude of the Indonesian Nation and State is by the nation's guidelines, namely Pancasila. It is sufficient to meet the needs of readers with material that is easy to understand and with clear explanations of topics and sub-topics.

There is a lot of new information presented. Namely an explanation of axiology and how humans should use the knowledge they have, as well as the sources of knowledge and how to get knowledge down to the nature of knowledge. It also explains the meaning of values, ethics, and morals from the point of view of axiology and philosophy.

The book is certainly able to have a good influence on readers. Readers can understand the philosophy associated with practical human action. From the book, the reader can also find out the meaning of Pancasila morality and how to behave following the moral values of Pancasila.

The book influences readers by explaining axiology and how it relates to values and other sciences. By reading this book, readers can be influenced by how humans look back on the meaning of ethics and morals and how to apply good ethics in real life. 
The author provides evidence in the form of case examples to strengthen his argument. One example is in terms of value. Value has properties that can only be experienced and felt through reason. One can feel directly the quality of a value or object that gives something good. In this case, the author provides evidence that someone who helps poor and needy people will feel the quality of the goodness of what he has done.

The evidence is strengthened by the statements of experts who support the arguments and evidence presented by the author. It presents many quotes and statements from experts that are relevant to the topics discussed in the book so that the author's argument becomes stronger.

In terms of value, the authors provide evidence to explain the classification value and provide exemplarily related cases. It is explained that the classification of values is based on the relationship generated by values with other things that are better, so that certain values are considered systematically lower or higher hierarchically than other values. A case in point is thriftiness which is classified as lower than the affluent nature in terms of meeting daily needs. (Page: 74)

The writing style can make it easier for readers to understand the contents of the book by providing examples of relevant cases. The author also provides several examples according to the discussion category. Book organization is well integrated by dividing each topic into subtopics. It can make the reader feel easier in understanding the content of each sub-topics.

The author pays attention to studies, facts, and ideas that the reader can consider. The author provides complete ideas and is supported by studies and thoughts from other researchers relevant to the topic of discussion.

The author describes axiology and how axiology relates to ethics and morals in different ways. It also explains the understanding of Pancasila morals and how Pancasila morals can affect the personality of the Indonesian nation. The advantage of this book is that it is written in clear and good language so that readers can understand the contents of the book well. In addition, the size of the book is not too thick so that it makes readers feel less heavy when reading it.

The weakness of the book is that as a book published in 2020, this book uses references that are too old, such as references from books in 1963, 1969, 1972, 1985. It can reduce the validity of the book because the possibility of previous facts has changed and is different from the conditions now. In addition, this book does not contain a biography of the author, so that the reader cannot know who is the author or author of this book more clearly.

The book is very good, explains axiology and its effects on several aspects of science, and shows how the attitude of the Indonesian Nation and Society is following the nation's guidelines, namely Pancasila. As well as explaining the ethics and morals that the Indonesian nation should uphold in facing the current modernization. This book is suitable for reading by students, workers in the field of education, and the general public. My suggestion is that the author can publish a second version by providing more recent references. It is also hoped that the author will add a biographical page of the author so that readers can find out who is the author of the book more clearly.

Febrinda Setyo Damayanti \& Moses Glorino Rumambo Pandin Airlangga University

\section{REFERENCE}

1. Jirzanah. (2020). AKSIOLOGI: Sebagai Dasar Pembinaan Kepribadian Bangsa dan Negara Indonesia. Yogyakarta: UGM Press.

2. UGM Press. Available at http://ugmpress.ugm.ac.id/id/writer/detail/jirzanah

\section{AUTHOR:}

Jirzanah was born in Yogyakarta, June 23, 1959. Her last degree was obtained from Gadjah Mada University, majoring in philosophy. Since 1989 until now he has been a permanent lecturer at the Faculty of Philosophy, Gadjah Mada University. The main subjects being taught are Philosophy of Values and Philosophy of Pancasila. 